\title{
Erratum to: Multi-year observations on the gametogenic ecology of the Antarctic seastar Odontaster validus
}

\author{
Laura J. Grange $\cdot$ Paul A. Tyler $\cdot$ Lloyd S. Peck
}

Published online: 11 April 2011

(C) Springer-Verlag 2011

Erratum to: Mar Biol (2007) 153:15-23

DOI 10.1007/s00227-007-0776-Z

Due to an unfortunate error, the original version of this article has been published with an error in the reference citation. It should be Brockington et al. (2007) instead of Brockington et al. (2006).

The correct "Brockington et al." reference is given below.

Brockington S, Peck LS, Tyler PA (2007) Gametogenesis and gonad mass cycles in the common circumpolar Antarctic echinoid Sterechinus neumayeri. Mar Ecol Prog Ser 330:139-147

The online version of the original article can be found under doi:10.1007/s00227-007-0776-z.

L. J. Grange $(\bowtie) \cdot$ P. A. Tyler

School of Ocean and Earth Science,

University of Southampton, NOC,

Southampton SO14 3ZH, UK

e-mail: laura_grange@hotmail.com

L. S. Peck

British Antarctic Survey, High Cross,

Madingley Road, Cambridge CB3 OET, UK 